\title{
MUTU MIKROBIOLOGIS BAKSO IKAN YANG DIRENDAM ASAP CAIR, DIKEMAS VAKUM, DIPASTEURISASI DAN DISIMPAN PADA SUHU DINGIN
}

\author{
Oktavianus Alexander Poluakan ${ }^{1}$, Henny Adeleida Dien ${ }^{2}$ dan Frans Gruber Ijong ${ }^{2}$ \\ 1) Mahasiswa pada Program Studi Teknologi Hasil Perikanan FPIK Unsrat Manado \\ ${ }^{2)}$ Staf pengajar pada Program Studi Teknologi Hasil Perikanan FPIK Unsrat Manado \\ Email: alexanderocta@gmail.com
}

\begin{abstract}
Fish meatball is a processed fish product and quite popular for the public. The weakness of fish meatball is quickly decayed which is caused by the growth of spoilage bacteria and pathogens during the storage. Liquid smoke has a function as a barrier to the development of bacteria. Pasteurization, vacuum packaging and storage of cold temperatures could inhibit the growth of bacterium. The purpose of these study is to assessment the Total Plate Count, Total Coliform and Escherichia coli, and Total Salmonella for the microbiological quality of fish meatball soaked in liquid-smoked, vacuum packed, pasteurized and stored at cold temperatures. Fish meatball soaked in liquid smoke $0.8 \%$ for 30 minutes and pasteurized at temperature of $\pm 88^{\circ} \mathrm{C}$ for 30,60 and 90 minutes, then vacuum packed and stored at cold temperatures. Based on the results of observations, Total Plate Count from fish meatball can last up for 10 days with the highest TPC value of $6.3 \times 104$ CFU / g according to ISO 7266: 2014. Total Salmonella until a 20th day had a negative value. Also, Total Coliform and E. coli growth does not found in the cold storage for 30 days. Value fish balls high water content and $\mathrm{pH}$ are good for bacterial growth. Immersion in liquid-smoked indicates that liquid-smoked is a good antibacterial preservative for use as an additive.
\end{abstract}

Keyword: $\quad$ Fish Meatball, Liquid-Smoked, Pasteurization, Bacteria.

Bakso ikan merupakan produk olahan ikan yang cukup digemari masyarakat. Kelemahan dari bakso ikan yaitu cepat mengalami pembusukan yang diakibatkan oleh pertumbuhan bakteri pembusuk dan patogen selama masa simpan. Asap cair memiliki fungsi sebagai penghambat perkembangan bakteri. Pasteurisasi, Pengemasan secara vakum dan penyimpanan suhu dingin dilakukan untuk menghambat pertumbuhan bakteri. Penelitian ini bertujuan untuk menghitung Angka Lempeng Total, Total Salmonella dan Total Koliform dan Escherichia coli terhadap mutu mikrobiologis bakso ikan yang direndam asap cair, dikemas vakum, dipasteurisasi dan disimpan pada suhu dingin. Bakso direndam pada asap cair $0.8 \%$ selama 30 menit dan dipasteurisasi pada suhu $\pm 88^{\circ} \mathrm{C}$ selama 30,60 dan 90 menit, lalu dikemas vakum dan disimpan pada suhu dingin. Berdasarkan nilai hasil pengamatan Angka lempeng Total, bakso ikan dapat bertahan selama 10 hari dengan nilai ALT tertinggi $6.3 \mathrm{x} 104 \mathrm{CFU} / \mathrm{g}$ dan masih dapat diterima SNI 7266:2014. Total Salmonella sp sampai pada hari ke 20 memiliki nilai negative dan Total Koliform dan E. coli tidak terdeteksi pertumbuhan sampai pada penyimpanan dingin selama 30 hari. Nilai kadar air bakso ikan tinggi dan $\mathrm{pH}$ yang baik untuk pertumbuhan bakteri. Perendaman dalam asap cair menunjukkan bahwa asap cair merupakan pengawet antibakteri yang baik untuk digunakan sebagai bahan tambahan.

Kata Kunci: Bakso Ikan, Asap Cair, Pasteurisasi, Bakteri.

\section{PENDAHULUAN}

Ikan merupakan salah satu sumber protein yang sangat penting untuk kebutuhan gizi manusia dan sangat baik untuk industri perikanan, karena memiliki prospek cerah. Bakso ikan merupakan salah satu produk olahan ikan yang cukup digemari masyarakat, karena rasanya enak dan cara penyajiannya mudah serta bisa disajikan dengan menu makanan lainnya. Kelemahan dari bakso ikan yaitu cepat mengalami pembusukan yang diakibatkan oleh pertumbuhan bakteri pembusuk dan patogen selama masa simpan, sehingga akan mengakibatkan gangguan terhadap keamanan pangan (food safety). Cara yang dilakukan untuk menekan pertumbuhan bakteri pembusuk dan bakteri patogen dalam penyimpanan produk pangan diantaranya adalah penggunaan asap cair. Asap cair merupakan bahan kimia hasil destilasi asap hasil pembakaran. Selain asap cair, juga digunakan kemasan vakum yaitu pengosongan udara untuk menghambat pertumbuhan bakteri aerob yang selanjutnya 
dilakukan pasteurisasi. Pasteurisasi adalah perlakuan panas yang diberikan pada bahan baku dengan suhu antara $75^{\circ} \mathrm{C}-90^{\circ} \mathrm{C}$. Salah satu tujuan pasteurisasi adalah untuk memperpanjang daya simpan bahan atau produk. Menurut zuraida (2009) Bakso ikan tanpa bahan tambahan hanya dapat bertahan \pm 16 jam, sedangkan dengan penambahan asap cair $2,5 \%$ dapat bertahan \pm 8 hari pada suhu dingin.

\section{METODOLOGI PENELITIAN}

Metode yang digunakan dalam penelitian ini merupakan metode deskriptif. Penelitian ini menggunakan Rancangan Acak Lengkap (RAL) yang disusun secara faktorial 3 x 4 dengan 2 kali ulangan.

\section{Bahan}

Sampel bakso ikan yang digunakan adalah bakso ikan yang dibeli dari rumah makan Mutiara, Paal II. Asap cair yang digunakan sebanyak $0,8 \%$. kemasan vakum menggunakan plastik retort pouch (RP) dengan ukuran $14 \times 19,5 \mathrm{~cm}$ dan divakum menggunakan mesin vakum stand model. Kemudian direndam air panas $\pm 88^{\circ} \mathrm{C}$ selama $30,60,90$ menit, kemudian disimpan dalam kulkas dengan suhu $\pm 5^{\circ} \mathrm{C}$. Analisis Mikrobiologi dan Kimia yang dilakukan meliputi : Angka Lempeng Total (ALT) menggunakan Media Nutrient Agar (NA), Total Salmonella menggunakan media Bismuth Sulphite Agar (BSA), Total Koliform dan Escherichia coli Menggunakan Metode MPN, Kadar Air sesuai SNI-01-2354.2-2006 dan $\mathrm{pH}$ menggunakan $\mathrm{pH}$ meter.

\section{HASIL DAN PEMBAHASAN}

\section{Analisis Angka Lempeng Total}

Data hasil analisis ALT dari bakso ikan yang direndam asap cair, dikemas vakum, dipasteurisasi dan disimpan pada suhu dingin dapat dilihat pada tabel 1 .

Berdasarkan hasil analisis, dapat dilihat bahwa perlakuan pasteurisasi selama 30 menit pada pengujian hari ke-0 memiliki nilai ALT $<30$ dan 4,7 x $10^{3} \mathrm{CFU} / \mathrm{g}$. Pasteurisasi selama 60 menit memiliki nilai ALT $6,7 \times 10^{2} \mathrm{CFU} / \mathrm{g}$ dan $7,5 \times 10^{3} \mathrm{CFU} / \mathrm{g}$. Pasteurisasi selama 90 menit memiliki nilai ALT $<30$ dan $<30$. Pada analisis hari ke-10, pasteurisasi selama 30 menit memiliki nilai ALT $6,3 \times 10^{4} \mathrm{CFU} / \mathrm{g}$ dan $<30$. Pasteurisasi selama 60 menit memiliki nilai ALT 4,9x10 $\mathrm{CFU} / \mathrm{g}$ dan $<30$. Pasteurisasi selama 90 menit memiliki nilai ALT $3,4 \times 10^{4}$ $\mathrm{CFU} / \mathrm{g}$ dan $<30$. Pengujian hari ke-20 dan 30 telah terjadi peningkatan ALT yang sangat banyak sehingga memiliki nilai Terlalu Banyak Untuk Dihitung (TBUD). Analisis sampel awal yaitu bakso yang tidak direndam asap cair dan tidak dipasteurisasi memiliki nilai Angka Lempeng Total $5,0 \times 10^{3} \mathrm{CFU} / \mathrm{g}$, sedangkan sampel yang direndam asap cair dan tidak dipasteurisasi memiliki nilai $4,8 \times 10^{2} \mathrm{CFU} / \mathrm{g}$. Hal ini menunjukkan bahwa sampel bakso ikan yang direndam asap cair dan tidak dipasteurisasi memiliki nilai ALT yang lebih kecil dibanding dengan sampel bakso ikan yang tidak direndam dengan asap cair dan tidak dipasteurisasi. Hal tersebut menunjukkan bahwa asap cair memiliki beberapa keunggulan salah satunya memiliki aktivitas antibakteri (Muratore et al, 2007).

Tabel 1. Data Hasil ALT Bakso Ikan yang Direndam Asap Cair, Dikemas Vakum, Dipasteurisasi dan Disimpan pada Suhu Dingin.

\begin{tabular}{|c|c|c|c|c|c|}
\hline \multirow{2}{*}{$\begin{array}{c}\text { Sampel } \\
\text { (Pasteuris } \\
\text { asi) }\end{array}$} & \multirow[b]{2}{*}{$\begin{array}{c}\text { Ulang } \\
\text { an }\end{array}$} & \multicolumn{4}{|c|}{ Nilai ALT (CFU/g) } \\
\hline & & $\begin{array}{c}\text { Penguji } \\
\text { an } \mathrm{H}-0\end{array}$ & $\begin{array}{l}\text { Penguji } \\
\text { an H-10 }\end{array}$ & $\begin{array}{l}\text { Penguji } \\
\text { an } \mathrm{H}-20\end{array}$ & $\begin{array}{l}\text { Penguji } \\
\text { an } \mathrm{H}-30\end{array}$ \\
\hline \multirow{2}{*}{30 menit } & 1 & $<30$ & $6,3 \times 10^{4}$ & TBUD & TBUD \\
\hline & 2 & $4,7 \times 10^{3}$ & $<30$ & TBUD & TBUD \\
\hline \multirow{2}{*}{60 menit } & 1 & $6,7 \times 10^{2}$ & $4,9 \times 10^{3}$ & TBUD & TBUD \\
\hline & 2 & $7,5 \times 10^{3}$ & $<30$ & TBUD & TBUD \\
\hline \multirow{2}{*}{90 menit } & 1 & $<30$ & $3,4 \times 10^{4}$ & TBUD & TBUD \\
\hline & 2 & $<30$ & $<30$ & TBUD & TBUD \\
\hline
\end{tabular}

\section{Analisis Total Salmonella}

Hasil analisis di atas menunjukkan bahwa bakso ikan yang direndam asap cair, dikemas vakum dan dipasteurisasi sampai hari ke-20 masih dapat diterima oleh konsumen, sedangkan pada analisis hari ke-30 tidak sesuai dengan persyaratan SNI 7266:2014. Sampel awal yaitu bakso ikan yang tidak direndam asap cair dan tidak dipasteurisasi memiliki nilai negatif begitu juga dengan sampel yang direndam asap cair dan tidak dipasteurisasi memiliki nilai negatif. Hal tersebut sesuai dengan pernyataan Yuliana (2011) bahwa asap cair dapat menghambat pertumbuhan bakteri Salmonella dan jamur Rhizopus. Salmonella rentan terhadap panas sehingga pasteurisasi cukup untuk membunuh salmonella pada makanan dengan kelembapan tinggi (Aminah, 2014). Salmonella bersifat aerob dan anerob fakultatif sehingga pengemasan secara vakum sangat baik digunakan untuk menghambat pertumbuhan Salmonella karena prinsip dari 
pengemasan vakum adalah penghampaan udara dalam kemasan. Penyimpanan pada suhu dingin sangat baik dilakukan karena bakteri Salmonella typhi tidak dapat hidup pada suhu di bawah $15^{\circ} \mathrm{C}$ dan di atas $41^{\circ} \mathrm{C}$. Suhu optimum pertumbuhan bakteri Salmonella typhi adalah $37,5^{\circ} \mathrm{C}$. Pada analisis hari ke 30 telah terjadi pertumbuhan Salmonella yang sangat banyak yang diakibatkan oleh aktivitas kimia mikroba yang menyebabkan terjadinya pertumbuhan bakteri.

\section{Analisis Total Koliform dan E. coli}

Pengujian total koliform dan total $E$. coli merupakan persyaratan mutu dan keamanan bakso ikan sesuai dengan SNI 7266:2014. Berdasarkan hasil pengamatan selama penyimpanan dingin sampai hari ke-30, nilai total koliform dan total E. coli untuk bakso ikan yang direndam asap cair, dipasteurisasi dan dikemas secara vakum adalah (-) negatif. Hal tersebut menunjukkan bahwa bakso ikan yang direndam asap cair, dikemas vakum dan dipasteurisasi diterima sesuai dengan SNI 7266:2014 dengan persyaratan E. coli adalah < 3. Sampel awal yaitu bakso ikan yang tidak direndam dengan asap cair dan tidak dipasteurisasi memiliki nilai $E$. coli negatif, begitu juga nilai $E$. coli sampel bakso ikan yang direndam asap cair tetapi tidak dipasteurisasi adalah negatif. Hal ini sesuai dengan pernyataan Panagan dan Syarif (2009) bahwa asap cair dapat menghambat pertumbuhan $E$. coli dan bersifat bakterisidal kuat. Forsythe dan Hayes (1998) juga menyatakan bahwa proses pasteurisasi ditujukan untuk membunuh bakteri patogen, merusak membran sitoplasma dan menghambat kerja enzim dapat mengganggu metabolisme sel bakteri. Penyimpanan dingin secara drastis memperlambat pembelahan $E$. coli namun tidak sepenuhnya menghentikannya. Penyimpanan dingin merupakan langkah penting dalam memperlambat pertumbuhan $E$. coli, tetapi tidak akan memperkecil populasinya (amazine, 2015).

\section{Analisis Kadar Air}

Berdasarkan data di atas, nilai rata-rata kadar air untuk sampel bakso ikan yang direndam asap cair dan dipasteurisasi selama 30 menit selama penyimpanan dingin adalah 70,03 $\%$, Sampel bakso ikan yang direndam asap cair dan dipasteurisasi selama 60 menit memiliki nilai rata-rata kadar air $73,46 \%$, dan sampel bakso ikan yang direndam asap cair dan dipasteurisasi selama 90 menit memiliki nilai rata-rata kadar air 73,37\%. Berdasarkan persyaratan mutu dan keamanan bakso ikan dalam SNI 7266:2014, kadar air maksimal adalah $65 \%$. Nilai hasil pengamatan tersebut menunjukkan bahwa bakso ikan memiliki kadar air yang cukup tinggi. Kadar air sampel awal yaitu tanpa direndam asap cair dan tidak dipaseurisasi memiliki kadar air 70,14\% dan sampel yang direndam asap cair dan tidak dipasteurisasi memiliki kadar air 73,09\%. Semakin rendah kadar air, semakin lambat pertumbuhan mikroba sehingga bahan pangan tersebut dapat tahan lama (Winarno, 1997), jika kadar air pada produk bakso ikan terlalu tinggi akan mengurangi keawetan produk karena bakteri dan jamur mudah berkembang biak (Fardiaz, 1989).

\section{Analisis pH}

Nilai $\mathrm{pH}$ sampel awal yaitu tanpa direndam asap cair dan tidak dipaseurisasi yaitu 5,97 dan sampel yang direndam asap cair dan tidak dipasteurisasi memiliki nilai $\mathrm{pH}$ 6,14. Hal tersebut menunjukkan terjadinya peningkatan $\mathrm{pH}$ setelah bakso direndam asap cair. Menurut Winarno (1980), faktor-faktor yang mempengaruhi pertumbuhan mikroba diantaranya $\mathrm{pH}$, kadar air, suhu dan oksigen. Kandungan asam dalam asap cair dapat mempengaruhi citarasa, $\mathrm{pH}$ dan umur simpan produk asapan; karbonil yang bereaksi dengan protein dan membentuk pewarnaan coklat dan fenol yang merupakan pembentuk utama aroma dan menunjukkan aktivitas antioksidan (Prananta, 2005).

\section{KESIMPULAN}

Berdasarkan hasil penelitian yang dilakukan, maka dapat ditarik kesimpulan sebagai berikut:

- Berdasarkan nilai hasil pengamatan Angka lempeng Total, bakso ikan yang direndam asap cair, dikemas vakum, dipasteurisasi dan disimpan pada suhu dingin dapat bertahan selama 10 hari dan masih dapat diterima sesuai SNI 7266:2014.

- Berdasarkan nilai hasil pengamatan Total Salmonella, bakso ikan yang direndam asap cair, dikemas vakum, dipasteurisasi dan disimpan pada suhu dingin selama 20 hari masih diterima SNI 7266:2014. 
- Berdasarkan nilai hasil pengamatan Total $E$. coli, bakso ikan yang direndam asap cair, dikemas vakum, dipasteurisasi dan disimpan pada suhu dingin dapat bertahan selama 30 hari dan masih diterima SNI 7266:2014.

\section{DAFTAR PUSTAKA}

amazine, 2015 Amazine. 2015. Efek Pendinginan dan Pemanasan pada Populasi Bakteri Escherichia coli. http://www.amazine.com. Diakses tanggal 10 juli 2015

Aminah, 2014 Aminah, S. 2014. Pengolahan Pangan dengan Suhu Tinggi. FIKKES-UNIMUS.

Fardiaz, 1989 Fardiaz, Srikandi. 1993. Analisis Mikrobiologi Pangan. Jakarta : PT.Raja Grafindo Persada.

Forsythe dan Hayes (1998) Forsythe, S.J. dan P.R., Hayes. 1998. Food Hygienes Microbiology and HACCP. Aspen Publishers, Gaithersburg. Maryland
Muratore et al, 2007 Muratore, G., Mazzaglia, A., Lanza, C.M., Licciardello, F. 2007. Process Variables on the Quality of Swordfish Fillets Flavored with Smoke Condensate. $\mathrm{J}$ of Food Processing and Presetvation 31: 167-177

Panagan dan Syarif (2009) Panagan A.T,. Syarif N,. 2009. Uji Daya Hambat Asap Cair Hasil Pirolisis Kayu Pelawan Terhadap Bakteri Escherichia coli., Jurusan Kimia FMIPA. Universitas Sriwijaya. Sumatra Selatan. Indonesia

SNI 7266:2014 Badan Standarisasi Nasional (BSN), 2014. SNI 7266:2014 Bakso Ikan. Jakarta : Badan Standarisasi Nasional.

Winarno, F.G. Dan T.S. Rahayu, 1994. Bahan Makanan Tambahan untuk Makanan dan Kontaminan. Pustaka Sinar Harapan.

zuraida (2009) Zuraida I, Hasbullah P, Sukarno, Budijanto S, Prabawati S, Setiadjit,. 2009. Aktifitas Antibakteri Asap Cair dan Daya Awetnya Terhadap bakso Ikan. Institut Pertanian Bogor. Bogor. 